\title{
Protein SI00B: a potential biomarker that correlates with clinical neurological variables in pediatric patients with congenital heart disease?
}

\begin{abstract}
Objectives: S100B protein has been proposed as a brain injury biomarker in several clinical scenarios. We aimed to determine whether a correlation exists between S100B serum levels and clinical variables at the pre-operative period of paediatric patients with congenital heart disease.

Methods: A prospective case-control study was designed including paediatric patients from one month to with congenital heart disease admitted for surgical treatment during a 3-month period. We studied 44 patients at the pre-operative period and divided them in two groups: 20 with clinical neurological variables and 24 without them. Clinical paediatric neurological variables were obtained, and serum levels of S100B protein were measured using the ELISA "sandwich" technique.
\end{abstract}

Results: The cut-off for S100B serum level in patients with clinical neurological variables was $16 \mathrm{pg} / \mathrm{ml}$, with sensibility and specificity values of $70 \%$ and $70.8 \%$, respectively. $\mathrm{S} 100 \mathrm{~B}$ protein levels greater than $16 \mathrm{pg} / \mathrm{ml}$ correlated with clinical neurological variables $(\mathrm{p}=0.014, \mathrm{OR}=2.556$, and $95 \% \mathrm{CI}=1.205-5.418)$

Neurological clinical variables before operation may modify operative resilience and the risk of neurological complications

Keywords: biomarkers, neurological variables, congenital heart disease
Volume 4 Issue 4 - 2018

\author{
Luis Antonio Pando Orellana, ,,2 Juan \\ Calderón Colmenero, ${ }^{2}$ Nancy Lucero \\ Martínez Rodríguez, ${ }^{2}$ Leonardo Del Valle \\ Mondragón, ${ }^{3}$ Víctor Manuel Espinoza \\ Gutiérrez, ${ }^{2}$ Jorge Luis Cervantes Salazar, ${ }^{2}$ \\ Juan Verdejo Paris, ${ }^{2}$ Alfonso Buendía \\ Hernández, ${ }^{2}$ Armando Vega López,' Pedro \\ José Curi Curi² \\ 'Escuela Nacional de Ciencias Biológicas, Instituto Politécnico \\ Nacional, México \\ ${ }^{2}$ Departamento de Cardiología Pediátrica, Instituto Nacional de \\ Cardiología Ignacio Chávez, México \\ ${ }^{3}$ Departamento de Farmacología, Instituto Nacional de \\ Cardiología Ignacio Chávez, México
}

\author{
Correspondence: Pedro José Curi Curi, Juan Badiano No.I, \\ Col. Sección XVI, Del.Tlalpan, 14080, México D.F., México, Tel \\ OI(52) 5573 29II, Fax 55(55) 55730994 \\ Email pcuricuri00।@gmail.com
}

Received: July 13, 2018 | Published: July 24, 2018

Abbreviations: $\mathrm{PET} / \mathrm{CT}$, computed tomography combined with positron emission tomography; SPECT, single positron emission tomography; RAGE, advanced glycation end products

\section{Introduction}

S100B belongs to the calmodulin family and is an EF-hand protein discovered by Moore in 1966 as a fraction of the brain in a $100 \%$ sulphur solution. S100B is a universal animal protein and probably functions as a neural growth factor. ${ }^{1,2}$ Congenital heart diseases are the most frequent malformations in the paediatric population, with a prevalence of 6 to 8 cases per 1000 live births. ${ }^{3}$ Advances in diagnosis and surgical techniques have allowed many patients to reach adulthood, but the risk of central nervous system damage continues to be one of the most feared morbidities in cardiovascular surgery., but only 8 per 1000 new-borns have a congenital heart disease , $^{3,5-11}$ and that are at the postoperative period on a long term basis, $, 3,7,70-15$ The first diagnostic approach for neurological disorders is made by means of a clinical neurological examination and history. Ideally, such as computed tomography, PET/CT (CRANIAL) and SPECT. These studies cannot be performed immediately in the new-born or infant period due to haemodynamic instability, ventilator-dependent patients, unavailability or increased costs. In addition to these factors, the studies can lead to quantifying neurological damage as a whole to predict clinical outcome. Infrastructure and expertise also require major medical facilities; therefore, a biological maker could facilitate the task by selecting candidates to the complete functional imaging tests, neurophysiological protocols, and 3D anatomical imaging with the correct biomarker or biomarkers for a proper triage before referral to level III of medical attention.
A biomarker is therefore needed not only to detect brain damage but also to predict the clinical brain metabolic outcome. The S100B protein, which was identified in the brain, is produced by astrocytes in physiological conditions in children with congenital heart disease ${ }^{16}$ and in different clinical scenarios, such as cranial trauma, cerebral ischaemia, neurodegenerative disorders, chronic inflammatory cerebral disease, cardiac arrest, and cardiopulmonary bypass. ${ }^{7,8,10-14,17-26}$ The aim of this study is to determine any correlation between S100B protein serum concentration levels and clinical neurological abnormal variables or risk factors at the pre-operative period in paediatric patients with congenital heart disease.

\section{Methods}

\section{Study design}

We designed a prospective case-control study that included all paediatric patients (one month to 16 years old) with congenital heart disease admitted to our institution (National concentration heart disease institution) for surgical treatment in a 3-month period of time. The only exclusion criterion was: previous cardiac surgery or emergency surgery. A clinical neurological history was obtained with the informed consent of the parent, relative or closest person responsible for the patient. We emphasized obstetrical antecedents, such as prenatal control, perinatal, paediatric, cardiovascular and neurological parameters and considered major positive antecedents as follows: a history or report of pre-eclampsia, eclampsia, and APGAR score $<8$ at baseline and 5 minutes. Post-natal neurological variables considered as major positive variables included neurodevelopmental deficit, epilepsies (partial), syndromatic phenotype and/or genotype, 
and clinical neurological motor .Definitions of these terms were obtained from the respective clinical practices, particularly the neurodevelopmental unit of the Hospital Infanfil de México "Dr Federico Gomez", of which the first author was chairman, and the Consejo Mexicano de Pediatría (National Board of Pediatrics).

The remaining clinical factors, considered minor positive criteria, including demographic, anthropometric and complementary data, such as gender, weight, height, congenital heart disease type, and preoperative oxygen saturation, were also registered but do not add to the article except as cyanotic or acyanotic disease because of it's very complex terminology and at the end has to do just with these very generic terms in our data base and the purpose of the paper. Patients were divided in two groups: those with clinical positive variables and those without them. To include patients with clinical neurological positive variables, we required one positive major peri-natal criterion (antecedent before, during or after labour up to a month of age) and a positive major post-natal criterion (meaning from the second month on) or also at least two positive perinatal and/or two post-natal minor criteria. This study was approved by our institution's ethics committee, and signed consent was provided for every case enrolled.

\section{Determination of protein SI00B serum concentration level}

Peripheral blood samples were obtained from all patients at the pre-operative period and centrifuged at $3000 \mathrm{rpm}$ for 15 minutes at room temperature. Sample plasma aliquots were obtained and frozen at $-80^{\circ} \mathrm{C}$ until analysis. S100B serum levels were measured by an ELISA technique (S100B [Human] ELISA KIT, ABNOVA; KA0037) in two incubation periods for a total period of 120minutes. During the first incubation period, a monoclonal specific antibody was added (biotinylated anti S100B antibody) for 60minutes. Afterwards, HRPstreptavidin was added. After 30minutes of incubation and washing, the substrate solution was added. The reaction was stopped by the addition of an acid solution, and the absorbance of the resulting product was measured. The results were obtained using a standard curve of S100B in accordance with manufacturer's directions and were expressed as $\mu \mathrm{g} / \mathrm{L}$.

Table I Demographic categorical characteristics

\section{Statistical analysis}

All data were registered in a checklist at the pre-operative period. Information was stored in an electronic Excel page and processed with an SPSS statistical software version 21.0 (SPSS Inc., Chicago, Ill, USA). Quantitative variables are presented as means and variability ranges (minimum and maximum). Categorical data are presented by terms of frequency and percentages in relation to the population at risk. S100B protein serum concentration levels were plotted using a ROC curve for both groups of patients, and the area under the curve (AUC) was determined to compare them. Comparison of categorical variables between patients with clinical neurological background and the patients without it was performed by means of a Fisher's exact test. Odds ratios were also calculated with a $95 \%$ confidence interval (CI). For comparing quantitative variables that were normally distributed, we performed a Student t-test. Values of $\mathrm{p}<0.05$ were considered statistically significant.

\section{Results}

We included 44 patients divided in two groups in the final analysis: 20 with clinical neurological antecedents as defined and 24 without clinical neurological antecedents. The group with clinical neurological antecedents exhibited a significant difference in the presence of clinical neurological $(35 \%, n=7, p=0.015)$ compared with the group without clinical neurological antecedents. The remainder of variables did not exhibit significant differences, which lead to an appropriate comparability between groups (Table 1) (Table 2). The area under the curve (AUC) was 0.685 for the group with clinical neurological antecedents as defined and of 0.315 for the group without clinical neurological antecedents as defined. The cut-off S100B serum level to identify patients with clinical neurological antecedents was $16 \mathrm{pg} / \mathrm{ml}$, with sensibility and specificity values of $70 \%$ and $70.8 \%$, respectively. Correlation between S100B protein serum level and clinical neurological antecedents is presented in Table 3. High S100B protein serum concentration levels $>16 \mathrm{pg} / \mathrm{ml}$ correlate significantly with the presence of clinical neurological clinical variables or antecedents $(\mathrm{p}=0.014)$ with a 2.556 odds ratio (OR) and $95 \%$ confidence interval of 1.205 to 5.418

\begin{tabular}{|c|c|c|c|c|}
\hline \multirow[t]{2}{*}{ Variable } & & $\begin{array}{l}\text { With clinical neurological } \\
\text { antecedents/history (Low Apgar, } \\
\text { Fetal Suffering, Neurological } \\
\text { lateralization, Seizures, } \\
\text { Neurodevelopment alterations) }\end{array}$ & $\begin{array}{l}\text { Without clinical neurological } \\
\text { antecedents/history (Low Apgar, } \\
\text { Fetal Suffering, Neurological } \\
\text { lateralization, Seizures, } \\
\text { Neurodevelopment alterations) }\end{array}$ & \multirow[t]{2}{*}{$\mathbf{p}$} \\
\hline & & n (\%) & n (\%) & \\
\hline \multirow{3}{*}{ Gender } & Female & II (55\%) & $12(50 \%)$ & \multirow{3}{*}{0.771} \\
\hline & & & & \\
\hline & Male & $9(45 \%)$ & $12(50 \%)$ & \\
\hline \multirow{2}{*}{$\begin{array}{l}\text { Congenital } \\
\text { disease type }\end{array}$} & Non cianotic & $12(60 \%)$ & $15(62.5 \%)$ & \multirow{2}{*}{1.000} \\
\hline & Cianotic & $8(40 \%)$ & $9(37.5 \%)$ & \\
\hline \multicolumn{2}{|c|}{ Syndromatic antecedents (Down, 22 delecion) } & $4(20 \%)$ & $4(16.7 \%)$ & 1.000 \\
\hline
\end{tabular}


Table Continued

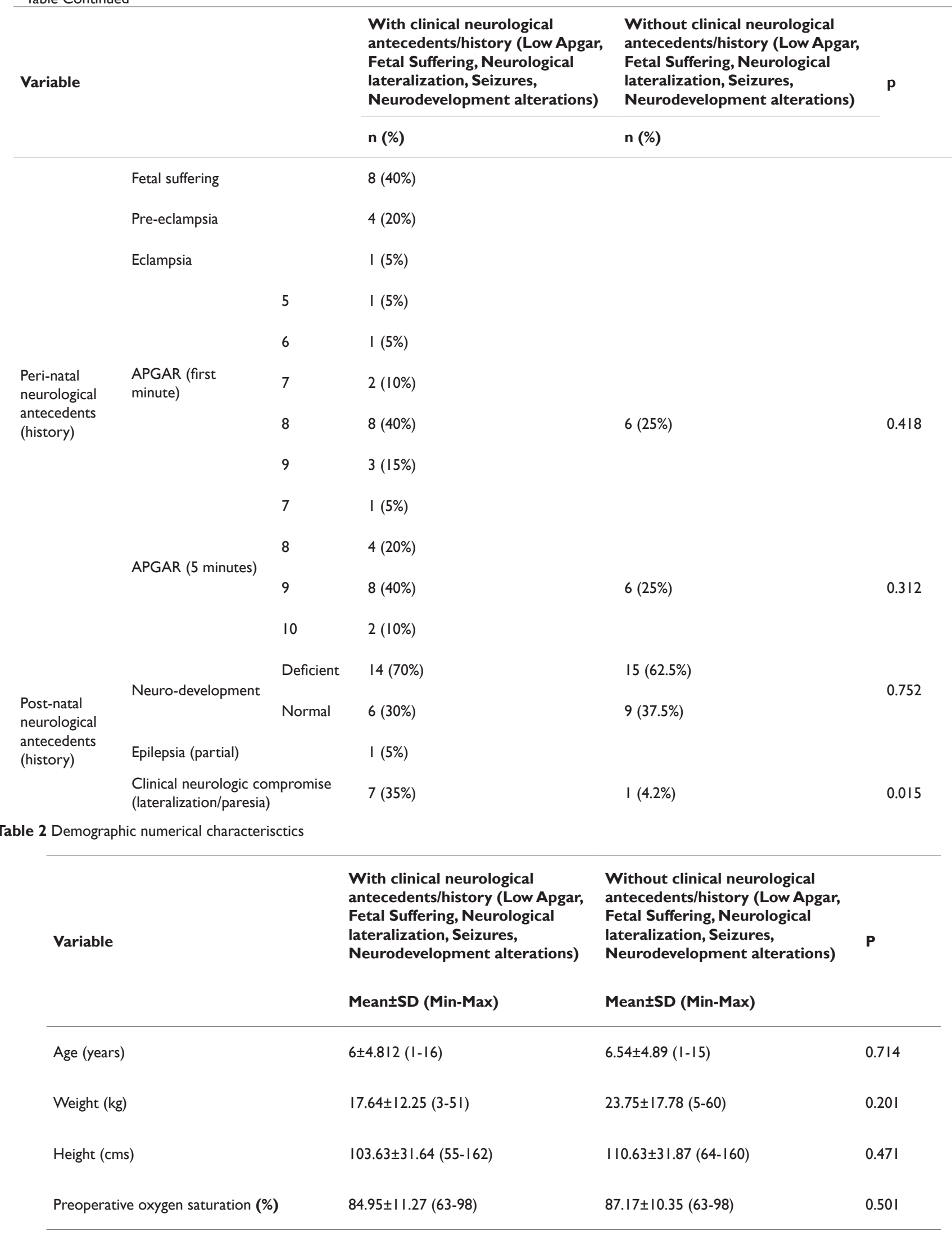


Table 3 Correlation between SI00B protein serum concentration levels and clinical neurological variables

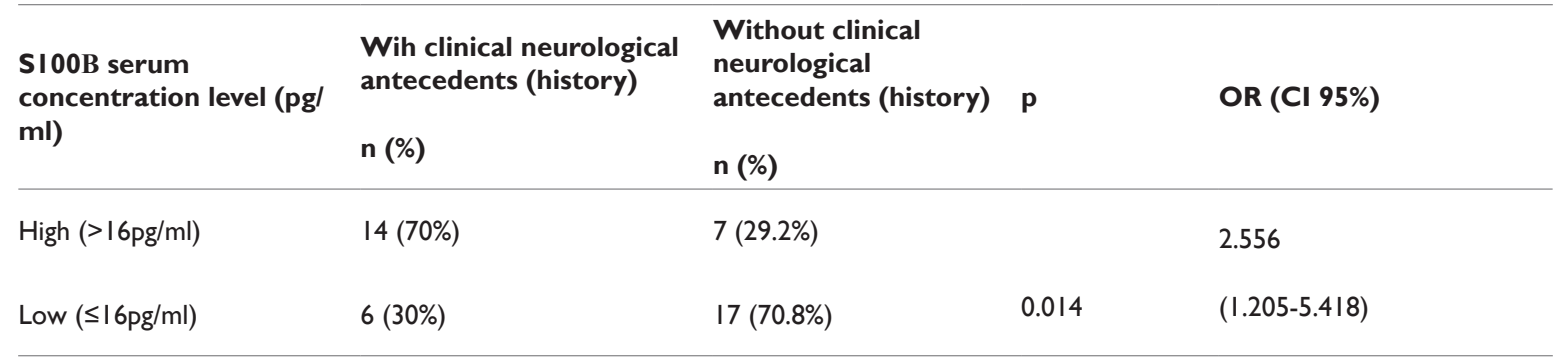

\section{Discussion}

A great variety of developmental disorders have been identified in up to $50 \%$ of the paediatric population in Latin America, but only 8 per 1000 new-borns have a congenital heart disease that modifies their development and resilience before, through and after cardiopulmonary bypass. These other factors include underweight, lower percentiles in height (in a Mexican population) ${ }^{12}$ and cognition deficits $^{6,27,28}$ that are typically detected during the postoperative period on a long- term basis. We observed that S100B protein levels greater than $16 \mathrm{pg} / \mathrm{ml}$ correlate with clinical abnormal neurological variables $(\mathrm{p}=0.014, \mathrm{OR}=2.556$, and $95 \% \mathrm{CI}=1.205$ - 5.418) and therefore may modify operative resilience and risk of neurological complications which have been reported in several articles ${ }^{3,5,29,30}$ Functional imaging studies cannot be performed immediately in the new-born or infant period because of haemodynamic instability, ventilator dependent patients, unavailability of infrastructure or costs. In addition to these factors, these studies can lead to quantify neurological damage as a whole to predict clinical outcome. Infrastructure and expertise require major medical facilities; therefore, as a biological maker, the S100B protein could facilitate the task by selecting patients who could be candidates for complete functional imaging tests, neurophysiological protocols, and 3D anatomical imaging. Thus selecting patients and costs in poor countries. The fact that $\mathrm{S} 100 \mathrm{~B}$ is comparable with neurological variables opens a line of research to consider how this correlation is involved given its role in the possible operative risk in patients who need cardiac surgery because of congenital heart disease cyanotic clinical (unsaturated with pulse oximetry: actually undergoing correlation with saturation under 80\%) and non-cyanotic clinical,(actually undergoing saturation above 80\%) clinical research; as well as with IOS index. This question should be of particular interest to the non-specialist because the diagnosis of congenital heart disease is at least suspected at the first and second level of health systems. Physicians that refer this group of patients to specialized centers must have access to an inexpensive biomarker to prioritize and alert the health system of risk factors, to improve triage referral protocols and to notify highly specialized centers of their behaviour while facing cardio-pulmonary bypass with possible insult to the brain and/or complications (3-7\%) according to our series ${ }^{3,12}$ Clinical anamnesis to obtain neurological data is difficult in paediatric populations with congenital heart disease for several reasons. Because of young age, physicians must ask to parents, relatives, closest persons or general paediatricians or even gynaecologists and obstetricians of the patient. Unfortunately, this is a problem that neurologists, cardiologists and physicians in general must address, particularly in developing countries. $^{2,5,7,9,18,20,31,32} \mathrm{~S} 100 \mathrm{~B}$ engages with RAGE receptors ${ }^{5}$ given that it is a cofactor in nitrogen reactive species. We are convinced that clinical correlations are trying to tell us something. However, given that children are different, it does not go alone. Previous communications tell us that the population under study must be stratified by age and that metabolic pro- and antioxidative items should be considered in addition to this important clinical-molecular correlation; the objective is to re-evaluate the value of S100B as a true and integral marker that can assess potential risks before congenital heart disease surgery and the inevitable and necessary comprehension of chronic hypoxia to fully understand the correlations established here between S100B and neurological variables..$^{33-53}$

\section{Author contributions}

a. Luis Antonio Pando-Orellana, MD: Concept/Design, Data analysis/interpretation, Drafting article, Critical revision of the article, Approval of article, Statistics, Overall-Data collection, Funding, and Responsible researcher.

b. Juan Calderón-Colmenero, MD: Data analysis/interpretation, Drafting article, Critical revision of the article, Approval of article, and overall Data collection

c. Nancy Lucero Martínez-Rodríguez, PhD: Data analysis/ interpretation, Drafting article, Critical revision of the article, Approval of article, Statistics, and laboratory Data collection

d. Leonardo Del Valle-Mondragón, PhD: Data analysis/ interpretation, Critical revision of the article, Approval of article, and laboratory Data collection

e. Víctor Manuel Espinoza-Gutiérrez, MD: Data analysis/ interpretation, Critical revision of the article, Approval of article, and Data collection

f. Jorge Luis Cervantes-Salazar, MD: Critical revision of the article, Approval of article, and Data collection

g. Juan Verdejo-Paris, MD: Critical revision of the article and Approval of the article

h. Alfonso Buendía-Hernández, MD: Critical revision of the article, Approval of article, and Data collection

i. Armando Vega-López, PhD. Critical revision of the article and Approval of article.

j. Pedro José Curi-Curi, MSc. Operative aspects, statistical collaboration and analysis and Approval of article

\section{Disclosure of grants or other funding}

The authors received no financial support for the research, authorship or publication of this manuscript 


\section{Acknowledgement}

None.

\section{Conflicts of interest}

The authors declare no potential conflicts of interest with respect to the research, authorship or publication of this manuscript.

\section{References}

1. Moore BW. A soluble protein characteristic of the nervous system. Biochem Biophys Res Commun. 1965;19(6):739-744.

2. Donato R. S100: a multigenic family of calcium-modulated proteins of the EF-Hand type with intracellular and extracellular roles. Int $J$ Biochem Cell Biol. 2001;33(7):637-668.

3. Calderón Colmenero J. Introducción. In: Attie F, Calderón-Colmenero J, Zabal C, Buendía A. Cardiología Pediátrica, editors. México: Editorial Medica Panamericana; 2013. p. 3-17.

4. Abdul Khaliq H, Blasig IE, Baur MO, et al. Release of the cerebral protein S-100 into blood after reperfusion during cardiac operations in infants: is there a relation to oxygen radical-induced lipid peroxidation. J Thorac Cardiovasc Surg. 1999;117(5):1027-1028.

5. Pando-Orellana L, Buendía-Hernandez A, Calderon-Colmenero JE, et.al. La importancia del binomio corazón cerebro en el manejo integral de las cardiopatías congénitas. Arch Cardiología Mex. 2010;80(4):249-254.

6. Miller SF, McQuillen PS, Hamrick S, et al. Abnormal brain development in newborns with congenital heart disease. $N$ Engl J Med. 2007;357(19):1928-1938.

7. Villarreal A, Seoane R, González Torres A, et.al. S100B protein activates a RAGE-dependent autocrine loop in astrocytes: implications for its role in the propagation of reactive gliosis. J Neurochem. 2014;131(2):190205 .

8. Angelo MF, Aguirre A, Avilés Reyes RX, et.al. The proinflammatory $\mathrm{RAGE} / \mathrm{NF}-\kappa \mathrm{B}$ pathway is involved in neuronal damage and reactive gliosis in a model of sleep apnea by intermittent hypoxia. PLoS One.2014;9(9):e107901.

9. Gonzalez FI, Miller SP. Does Perinatal asphyxia impair cognitive function without cerebral palsy?. Arch Dis Child Fetal Neonatal ed. 2006;91(6):F454-F4559.

10. Villarreal A, Aviles Reyes RX, Angelo MF, et al. S100B alters neuronal survival and dendrite extension via RAGE-mediated NF- $\mathrm{KB}$ signaling. $J$ Neurochem. 2011;117(2):321-32.

11. Zhang W, Potrovita I, Tarabin V, et al. Neuronal activation of NFkappaB contributes to cell death in cerebral ischemia. J Cereb Blood Flow Metab. 2005;25(1):30-40.

12. Calderón Colmenero J, Cervantes-Salazar JL, Curi-Curi PJ, et al. Problemática de las cardiopatías congénitas en México. Propuesta de regionalización. Arch Cardiol Mex. 2010;80(2):133-140.

13. Blomquist S, Johnsson P, Lührs C, et al. The appearance of S-100 protein in serum during and immediately after cardiopulmonary bypass surgery: a possible marker for cerebral injury. $J$ CardiothoracVasc Anesth. 1997;11(6):699-703.

14. Almaraz AC, Bobrow BJ, Wingerchuk DM, et al. Serum neuron specific enolase to predict neurological outcome after cardiopulmonary resuscitation: a critically appraised topic. Neurologist. 2009;15(1):44-8.

15. Fanó G, Mariggió MA, Angelella P, et al. The S-100 protein causes an increase of intracellular calcium and death of PC12 cells. Neuroscience. 1993;53(4):919-925.
16. Pando Orellana LA, Springall R, BojalilR, et al. Proteína S100B como marcador sérico predictivo del estado neurológico y del resultado preoperatorio en los pacientes pediátricos con cardiopatia congénita:un estudio piloto En III Congreso Nacional AMECC 2012, México: Querétaro; 2012.

17. Ali MS, Harmer M, Vaughan R. Serum S100 protein as a marker of cerebral damage during cardiac surgery. Br J Anesth. 2000;85(2):287298.

18. Aloe L. Rita Levi-Montalcini: The discovery of nerve growth factor and modern neurobiology. Trends Cell Biol. 2014;14(7):395-399.

19. Carrillo González NJ, Ortuño Sahagún D, Gudiño Cabrera C. Identificación de isoformas del mRNA del GFAP (Proteína Fibrilar Glial Acídica) en distintas regiones del sistema nervioso de la rata adulta. En: Avances en la investigación Científica en el CUCBA. Guadalajara, México: U. de G; 2005. p. 240-245.

20. Charpentier TH, Thompson LE, Liriano MA, et al. The effects of CapZ peptide (TRTK-12) binding to S100B-Ca2+ as examined by NMR and X-ray crystallography. J Mol Biol. 2010;396(5):1227-1243.

21. Claus W, Heizmann, Beat W, et al. The family of S100 cell signaling proteins. In: Ralph A, Bradshaw, editors. Handbook of Cell Signaling. Oxford U.K: Academic Press; 2009. p. 983-994.

22. Curi Curi PJ, Cervantes Salazar J, Calderón Colmenero J, et al. Resultados inmediatos en cirugía cardiovascular neonatal. Rev Invest Clin. 2012;64(2):199-206.

23. Breuer AC, Franco I, Marzewski D, et al. Left ventricular thrombi seen by ventriculography are a significant risk factor for stroke in open-heart surgery. Ann Neurol. 1981;10:103-104.

24. Donato R. Functional roles of $\mathrm{S} 100$ proteins, calcium-binding proteins of the EF-hand type. Biochim Biophys Acta. 1999;1450(3):191-231.

25. Drohat AC, Nenortas E, Beckett D, et al. Oligomerization state of S100B at nanomolar concentration determined by large-zone analytical gel filtration chromatography. ProteinSci. 1997;6(7):1577-1582.

26. Shinozaki K, Oda S, Sadahiro T, et.al. S-100B and neuron-specific enolase as predictors of neurological outcome inpatients after cardiac arrest and return of spontaneous circulation: a systematic review. Crit Care. 2009;13(4):R121.

27. Rosén H, Rosengren L, Herlitz J, et al. Increased serum levels of the S-100 protein are associated with hypoxic brain damage after cardiac arrest. Stroke. 1998;29(2):473-477.

28. Ingebrigtsen $\mathrm{T}$, Rommer $\mathrm{B}$, Kongstad $\mathrm{P}$, et al. Increased serum concentrations of protein S-100 after minor head injury: a biochemical serum marker with prognostic value. J Neurol Neurosurg Psychiatry. 1995;59(1):103-104.

29. Kilminster S, Treasure T, McMillan T, et al. Neuropsychological change and $\mathrm{S}-100$ protein release in 130 unselected patients undergoing cardiac surgery. Stroke. 1999;30(9):1869-1874.

30. Gazzolo D, Vinesi P, Geloso MC, et al. S100 blood concentrations in children subjected to cardiopulmonary by- pass. Clin Chem. 1988;44(5):1058-1060.

31. Sanchez Peña P, Pereira AR, Souror NA, et al. S100B as an additional prognostic marker in subarachnoid aneurysmal hemorrhage. Crit Care Med. 2008;36(8): 2267-2273.

32. Abdul Khaliq H, Blasig IE, Baur MO, et al. Release of the cerebral protein S-100 into blood after reperfusion during cardiac operations in infants: is there a relation to oxygen radical-induced lipid peroxidation. J Thorac Cardiovasc Surg. 1999;117(5):1027-1028. 
33. Markowitz SD, Ichord RN, Wernovsky G, et al. Surrogate markers for neurological outcome in children after deep hypothermic circulatory arrest. Semin Cardiothorac Vasc Anesth. 2007;11(1):59-65.

34. Aurell A, Rosengren LE, Karlsson B, et al. Determination of S-100 and glial fibrillary acidic protein concentrations in cerebrospinal fluid after brain infarction. Stroke. 1991;22(10):1254-8.

35. Marshak DR, Pesce SA, Stanley LC, et al. Increased S100 beta neurotrophic activity in Alzheimer's disease temporal lobe. Neurobiol Aging. 1992;13(1):1-7.

36. Usui A, Kato K, Abe T, et al. S-100ao protein in blood and urine during open-heart surgery. Clin Chem. 1989;35(9):1942-1944.

37. Vaage $\mathrm{J}$ Anderson R. Biochemical markers of neurologic injury in cardiac surgery: the rise and fall of S100B. J Thorac Cardiovasc Surg. $2001 ; 122: 853-855$

38. Selinfruend R, Barger SW, Pledger WJ, et al. Neurotrophic protein S100B stimulates glial cell proliferation. Proc Natl Acad Sci USA. 1991;88(9):3554-3558.

39. Haglid KG, Yang Q, Hamberger A, et al. S-100 $\beta$ stimulates neurite outgrowth in the rat sciatic nerve grafted with acellular muscle transplants. Brain Res. 1997;753(2):196-201.

40. Merkle FT, Tramontin AD, Garcia Verdugo JM, et al. Radial glia rise to adult neural stem cells in the subventricular zone. Proc Natl Acad Sci USA. 2004;101(50):17528-17532.

41. Yardan T, Erenler AK, Baydin A, et al. Usefulness of S100B protein in neurological disorders. J Pak Med Assoc. 2011;61(3):276-81.

42. Kleindienst A, Hesse F, Bullock MR, et al. The neurotrophic protein S100B: value as a marker of brain damage and possible therapeutic implications. Prog Brain Res.2007;161:317-25.

43. Apak R, Güçlü K, Ozyürek M, et al. Cupric ion reducing antioxidan capacity assay for antioxidants in human serum and for hydroxyl radical scavengers. Methods Mol Biol. 2010;594:215-39.
44. Sakimura K, Kushiya E, Ogura A, et.al. Upstream and intron regulatory regions for expression of the rat neuron-specific enolase gene. Brain Res Mol Brain Res. 1995;28(1):19-28.

45. Licht DJ, Shera DM, Clancy RR, et al. Brain maturation is delayed in infants with complex congenital heart disease. J Thorac Cardiovasc Surg. 2009;137:529-537.

46. Routsi C, Stamataki E, Nanas $\mathrm{S}$, et al. Increased levels of serum S100B protein in critically ill patients without brain injury. Shock. 2006;26(1):20-24.

47. Fillipidis AS, Papadopoulos DC, Kapsalaki EZ, et al. Role of the S100B serum biomarker in the treatment of children distress from mild traumatic brain injury. Neurosurg Focus. 2010;29(5):E2.

48. Marenholz I, Heizmann CW, Fritz. G. S100 proteins in mouse and man from evolution to function and pathology (including an update of the nomenclature). Biochem Biophys Res Commun. 2004;322(4):11111122 .

49. Multicenter trial of hemodilution in ischemic stroke: background and study protocol. Scandinavian Stroke Group. Stroke. 1985;16(5):885890

50. Waterloo K, Ingebrigtsen T, Rommer B. Neuropsychological function in patients with increased serum levels of protein S-100 after minor head injury. Acta Neurochir. 1997;139(1):26-32.

51. Mori T, Asano T, Town T. Targeting S100B in Cerebral ischemia and in Alzheimer's disease. Cardiovasc Psychiatry Neurol. 2010. p. 1-14.

52. Volpe JJ. Neurobiology of periventricular leukomalacia in the premature infant. Pediatr Res. 2001;50;553-562.

53. Fujita Y, Kuchimaru T, Kadonosono T, et al. In vivo imaging of brain ischemia using an oxygen-dependent degradative fusion protein probe. PLoSOne. 2012;7(10):1-7. 